\title{
Public Education Spending and Income Inequality in Bangladesh
}

\author{
Mohammad Rezaul Karim
}

\begin{abstract}
The aim of the article is to analyse the effects of public education and education spending of education on income distribution in Bangladesh. It follows the benefit incidence analysis (BIA) method using secondary data of 2010. As a result of public education spending, inequality decreases in Bangladesh. However, the rich people seem to be benefited more from each level of education particularly the high income group receives about $50 \%$ benefit from the public spending. Although the target of Bangladesh government is to reduce poverty and providing benefits to the poor, they are not ultimate beneficiaries. It demands to redesign the policy to set up more educational institutions in rural areas, special programmes like scholarship systems, loan system should be opened up for the poor income groups.
\end{abstract}

Index Terms - Benefit incidence analysis, public education spending, Bangladesh, inequality.

\section{INTRODUCTION}

Government formulates polices and implements programmes in order for development of socioeconomic condition of the country. As an integral of this, a numerous social welfare programmes such as basic education, basic health services, allowance for elderly people, youth development programmes are initiated. Social welfare spending particularly on education services is regarded as one of the effective instruments used to reduce inequality in income distribution and reduce the poverty[1]-[3]. Bangladesh government emphasizes on education and proliferates education expenditure leading to sustainable socioeconomic development. It is often asserted by policy makers in developing countries that markets do not work well for the poor, and public subsidies on education would correct for market imperfections and produce positive externalities. It is also argued in the literature that better education has spill over effect that contributes to economic growth, improve the status of poor and increase their chances for employment. However, benefits gained from different levels of education vary the degree where tertiary education brings the competitive advantage [4]. Developing countries generally maintain the pro-poor public spending on education for providing the benefits to the poor people of the country [4]-[6]. Bangladesh, as a developing country, emphasizes spending on education to minimize the gap between poor and rich. Benefit incidence analysis (BIA) method can be used to examine the ultimate beneficiaries

Manuscript received September 22, 2013; revised November 27, 2013.

Mohammad Rezaul Karim is with the National Institute of Development Administration, Bangkok, Thailand and Bangladesh Public Administration Training Centre, Savar, Dhaka, Bangladesh (e-mail: rezapatc@gmail.com). from the government spending. BIA is a process of computing the distribution of public expenditure across different demographic groups, such as women and men. The procedure involves allocating per unit public subsidies (for example, expenditure per student for the education sector) according to individual utilization rates of public services[7]-[9]. It is a tool used to assess how tax policy or government subsidy affects the distribution of welfare in the population. In other words, it evaluates the distribution of government subsidies among different groups in the population, in particular, most of benefit incidence analyses divide the population into sub-groups (e.g. quintiles or deciles) based on household per capita income. Since expenditures on education are expected to have a redistributive impact, BIA is centred on assessing whether public spending is progressive, that is, whether it improves the distribution of welfare, household income or expenditure. It estimates how much the income of a household would have to be raised if the household would fully pay for the subsidized public services [4], [7], [10].

This research has an attempt to analyse the effects of public education in terms of accessibility and education spending of education on income distribution which will examine the pre-expenditure and post-expenditure income distribution. In order to present and compare the result the analysis will be done based on income share of households and calculated Gini coefficient of Bangladesh before the government expenditure on education. The Second stage will be the detailed calculation of public expenditure on primary, secondary, tertiary education services. In the third stage it will be the calculation of household income distribution to what extend inequality increases or decreases after the public education spending.

\section{OBJECTIVES OF THE STUDY}

This study is designed to explore who are the ultimate beneficiaries of the public education in terms of accessibility that includes male-female, rural urban ratio and to what extend the public education spending minimizes the income inequality in Bangladesh.

\section{EDUCATION SYSTEM AND REFORMS IN BANGLADESH}

The education system in Bangladesh can be subsumed in three such as general education system, madrasah (religious) education system and technical - vocational education system. Each system has five levels of education which are primary level (years 1 to 5), junior level (years 6 to 8 ), secondary level (years 9 to 10), higher secondary level 
(years 11 and 12) and tertiary level. However, these have been categorized into three levels i.e. primary, secondary (junior, secondary, higher secondary) and higher education to analyse in this paper. Bangladesh government has taken some reform initiatives during the last four decades through several education reform commissions. Recently Bangladesh has enacted the Education Policy 2010 with a vision to create an active, knowledgeable, competent workforce.

\section{Public Education Spending in Bangladesh}

The increased number of population, necessity of the socio-economic development, demand of globalization, increase of national budget, inflation rate, and demand from civil society have led to proliferate the allocation in education spending in Bangladesh. Besides, the highest priority of Bangladesh Government is to provide quality education to all for which it emphasizes on the allocation in the national budget. The education sector receives a total 1474.76 million taka in 2012-2013 which is 10.9 percent of the national budget. It is the highest expenditure on social welfare spending. However, this expenditure was 1239.18 million taka (13.4\% of the national budget) in 2010-2011. The government increases the allocation on education budget every year. The total expenditure on education was $1.58 \%$ of total GDP in 1990 which increased to $2.23 \%$ in 2009.

\section{RESEARCH METHODOLOGY USED}

This research is a quantitative research conducted on the basis of secondary data. Benefit incidence analysis typically involves a five-step process [4], [11], [12].

- Enrolment distribution: Enrolment in three levels of education has been calculated by the number of children of each income group (decile or quintile) dividing into Rural-urban, male female categories.

- Average unit cost: It is calculated by dividing government spending on the service by the total number of users of the service. In case of public education users are students attending a school.

- Average benefit: It comes from government spending on a service is simply equated with the average unit cost of providing the service as derived from the previous step.

- Income group: The population of users (individuals or households) is ranked from poorest to richest using an income measure and is aggregated into income classes. Income classes can be deciles or quintiles.

- Distribution of benefit: it is calculated across the income classes is obtained by multiplying the average benefit derived from the previous stage by the number of users of the service in each income class. The quintile share of benefits accumulated to each income class from a public service is simply the total benefits thus derived for each class divided by the total spending on the service across all income classes. By construction, quintile shares for a given service add to unity.

- Comparison: Comparing the distributional effects of benefits with a number of benchmark distributions.

\section{Data Collection}

The main source of data collections are Ministry of Education, Bangladesh Bureau of Statistics, World Bank, various journals, articles, reports. This research covers three types of data to identify household's income and expenditure, and public spending.

TABLE I: DISTRIBUTION OF INCOME AND HOUSEHOLD CHARACTERISTICS AND EXPENDITURE BY EACH INCOME CLASS

\begin{tabular}{lccccc}
\hline & & & \multicolumn{3}{c}{$\begin{array}{c}\text { Proportion of number of students } \\
\text { enrolled at }\end{array}$} \\
\cline { 4 - 6 } $\begin{array}{l}\text { Income } \\
\text { class }\end{array}$ & $\begin{array}{c}\text { Income } \\
\text { per } \\
\text { month }\end{array}$ & $\begin{array}{c}\text { Percentage } \\
\text { of income }\end{array}$ & Primary & Secondary & Tertiary \\
\hline $\begin{array}{l}\text { Lowest } \\
\text { income }\end{array}$ & 2295 & 5.22 & 16.52 & 9.77 & 4.4 \\
$\begin{array}{l}\text { Low } \\
\text { income }\end{array}$ & 4002 & 9.1 & 19.53 & 13.36 & 7.69 \\
$\begin{array}{l}\text { Middle } \\
\text { income }\end{array}$ & 5862 & 13.33 & 21.03 & 19.54 & 10.99 \\
$\begin{array}{l}\text { High } \\
\text { income }\end{array}$ & 9041 & 20.56 & 21.67 & 25.41 & 23.08 \\
$\begin{array}{l}\text { Highest } \\
\text { income }\end{array}$ & 22775 & 51.79 & 21.25 & 31.92 & 53.85 \\
Total & 43975 & 100.0 & 100 & 100 & 100 \\
\hline Source: BBS, & 2010 & & & &
\end{tabular}

Source: BBS, 2010

\section{DISCUSSION AND ANALYSIS}

The benefit incidence analysis shows accessibility to education by demographic evaluation and the comparison of income distribution of households before and after the public expenditure. This paper analyses the access of rural urban male female students. And it presents the income distribution by following the steps according to methodology.

\section{A. Benefit Assumption of Public Expenditure on Education}

The direct beneficiaries of education spending are the students enrolled in education institutions and the employers who recruit the educated people. Although there is an indirect benefit affect the society creating the spill over effect. The benefit of education spending is distributed proportionately among the number of students enrolled at primary, secondary and tertiary level of education in each income class. So the assumption is students studying the primary and secondary level are the beneficiaries from this expenditure, on the other hand, students of university and vocational institutions get the benefits from public expenditure on tertiary education. However, basic education is a compulsory and free, lower-income household tends to receive more benefit from this spending whereas high income class people receive more benefit from the higher education spending since higher income households tend to go for higher studies.

In Bangladesh, Expenditure can be classified into basic and higher education where basic education includes primary, secondary, high school. Higher education includes vocational and university education. Although government, labour market and the society are benefitted from the educated people direct and indirectly, direct beneficiaries of education spending are the students that are enrolled in public educational institutions at each level of education [4]. 
Suppose, the government allocates $47.39 \%$ of the budget on basic education, $42.68 \%$ on secondary and $9.93 \%$ on higher education: About $45.39 \%$ of the benefit is distributed as proportion to the number of students enrolled at the basic education in each income class and $42.68 \% \& 9.93 \%$ for secondary and higher education respectively [1].

\section{B. Accessibility to Education}

Reference [13] shows that the average monthly income of people is 8795 taka that varies from 7592 in the rural area to 11778 taka in the urban area (Table I). The net attendance ratios in primary and secondary education are $84 \%$ (urban), $81 \%$ (rural) and $53 \%$ (urban), $48 \%$ (rural) respectively. Gender disparity lies also in the rural and urban secondary education. Gender parity index in secondary education is 1.08 for urban and 1.18 for rural.

The children from poor income group study in the rural schools particularly in primary and secondary schools. On the other hand, rich parents from urban and rural send their students to urban schools. However for higher education, there is no scope of study in the rural area. So everybody has to go to main cities of Bangladesh. Evidence suggests that women are poorer than men. So the enrolment of malefemale students in rural or urban is an indicator who gets the benefit from the public education and education spending in Bangladesh. The Table II shows that school enrolment for the case female is lower than male at all levels i.e. primary, secondary and tertiary. The overall enrolment in public school declined upto 2010 and started to increase from 2011 as an effect of elected government and reflection of median voters [13]. The main reasons are the political instability particularly in 2007 and 2008 when there was no elected government. This led to lowest school enrolment in public schools in 2009. The rise of private schools and their quality education attract parents to send their children to private schools. This table also tells about the higher enrolment rate is in the lower level education as the government provides free education facility. The overall enrolment rate is low because mostly poor income group parents send public school whereas rich people send their children to private, English medium schools or abroad.

TABLE II: SCHOOL ENROLMENT IN LEVEL OF EDUCATION BY SEX, 2001-2012

\begin{tabular}{lccccccccccccccc}
\hline School Enrolment (\%) & 2001 & 2002 & 2003 & 2004 & 2005 & 2006 & 2007 & 2008 & 2009 & 2010 & 2011 & 2012 & Average \\
\hline primary (female) & 54.49 & 53.83 & 57.66 & 59.28 & 54.79 & 58.36 & 56.16 & 55.49 & 54.42 & 69.7 & 69.82 & 74.27 & 69.82 \\
primary (male) & 89.35 & 88.26 & 82.33 & 83.14 & 89.94 & 83.42 & 81.04 & 80.29 & 78.71 & 86.59 & 86.07 & 87.97 & 86.07 \\
primary (Total) & 71.92 & 71.04 & 70 & 71.21 & 72.37 & 70.89 & 68.6 & 67.89 & 66.57 & 78.14 & 77.94 & 81.12 & 77.94 \\
secondary (female) & 6.84 & 9.01 & 6.25 & 8.55 & 11.25 & 12.03 & 11.64 & 12.77 & 12.87 & 13.13 & 13.32 & 13.87 & 13.32 \\
secondary (male) & 25.84 & 27.15 & 25.9 & 25.46 & 26.58 & 28.58 & 28.54 & 26.97 & 27.76 & 27.34 & 26.82 & 27.21 & 26.82 \\
secondary (Total) & 16.59 & 18.32 & 16.33 & 17.52 & 19.8 & 20.51 & 20.29 & 20.04 & 20.48 & 20.39 & 20.21 & 20.68 & 20.21 \\
tertiary (female) & 0.92 & 0.89 & 0.85 & 1.6 & 1.7 & 1.79 & 1.93 & 1.89 & 1.55 & 1.16 & 1.16 & 1.34 & 1.16 \\
tertiary (male) & 5.43 & 5.21 & 4.96 & 5.55 & 7.08 & 7.68 & 7.69 & 7.5 & 6.6 & 5.86 & 5.81 & 6.7 & 5.81 \\
tertiary (Total) & 3.23 & 3.11 & 2.96 & 3.64 & 4.48 & 4.83 & 4.9 & 4.78 & 4.15 & 3.58 & 3.56 & 4.1 & 3.56 \\
Average & 30.51 & 30.76 & 29.69 & 30.66 & 26.44 & 26.45 & 25.64 & 25.29 & 24.8 & 27.31 & 27.18 & 35.26 & 32.16 \\
\hline
\end{tabular}

Source: Author's calculation on the basis of data collected from BANBEIS

TABLE III: THE DisTRIBUTIONAL EFFECTS OF PUBLIC SPENDING (MILLION TAKA)

\begin{tabular}{|c|c|c|c|c|c|c|}
\hline \multirow[b]{2}{*}{ Types of Education } & \multirow[b]{2}{*}{ Total amount (Year 2010) } & \multicolumn{5}{|c|}{ Income Class } \\
\hline & & Lowest & Low & Middle & high & highest \\
\hline Primary & 85112.00 & $14,060.50$ & $16,622.37$ & $17,899.05$ & $18,443.77$ & $18,086.30$ \\
\hline percentage & 100.00 & 16.52 & 19.53 & 21.03 & 21.67 & 21.25 \\
\hline Secondary & $76,650.00$ & $7,488.71$ & $10,240.44$ & $14,977.41$ & $19,476.77$ & $24,466.68$ \\
\hline Percentage & 100.00 & 9.77 & 13.36 & 19.54 & 25.41 & 31.92 \\
\hline Tertiary & $17,830.00$ & 784.52 & $1,371.13$ & $1,959.52$ & $4,115.16$ & $9,601.46$ \\
\hline percentage & 100.00 & 4.40 & 7.69 & 10.99 & 23.08 & 53.85 \\
\hline Total & $179,592.00$ & $22,333.73$ & $28,233.94$ & $34,835.98$ & $42,035.70$ & $52,154.44$ \\
\hline percentage & 100 & 12.44 & 15.72 & 19.40 & 23.41 & 29.04 \\
\hline
\end{tabular}

Source: Author's Calculation

\section{The Distributional Effects of Public Education Expenditure}

It is depicted from the Table I that the poorest income class received the 16.52 percent of total education spending on primary education of Bangladesh government whereas top 20 percent rich people receive 21.25 . The similar trend is seen for secondary and higher education where the richest group receives 31.92 percent and 53.85 percent respectively whereas the poorest group receive only 9.77 percent and 4.40 percent respectively. It indicates the education spending in this sector is regressive. In higher education rich 40 percent enjoy the lion's share $(86.93 \%)$ of the total expenditure on tertiary education. This happens due to the solvency of the rich people who used to send their children for higher education. The students from this section utilize their human capital in such job position with a gain in higher rate. The opposite scenario works for the poor. This is why inequality increases in Bangladesh. In order for minimizing this rich and poor gap, Bangladesh government introduced female student stipend for poor which increases the enrolment but did not affect much on income inequality. The commercial banks provides education loan. The problem is that the financial institutions give loan to those students whose parents have the capability to pay back the loan which automatically favours the rich. Even private education institutions do not maintain the conditions so that poor can get the benefits. Policy makers found some vital 
reasons for not reaching the benefit to the poor [4].

\section{Calculation and Explanation of Benefit Incidence of Public Expenditure on Education}

The public expenditure is spent for doing the benefit for the people. However, benefit varies from one income class to another income class. Typically the following methods are followed for calculating public expenditure incidence.

If we see the public expenditure for education in terms of primary and secondary education poor are getting more benefits whereas for other purposes rich are getting most out of it (Table III). It means the public expenditure on welfare spending in Bangladesh is pro-rich other than pro-poor.

\section{E. Income Distribution before and after Expenditure}

There are several processes to examine the income distribution before and after public expenditure. The decrease and increase in inequality can be seen by adding the public expenditure. Reference[14] explains that the post income distribution can be estimated simply by adding the absolute benefits to corresponding household incomes and re-computing the new contribution. This will show whether the inequality in Bangladesh increases or not. This research paper explains the empirical research.

The other measure is Gini coefficient by which the inequality trend can also be measured. This can be calculated in pre and post expenditure and then compared. The Gini coefficient measures the inequality among values of a frequency distribution, popularly used in measuring wealth or income inequality. The Gini index in Bangladesh is 0.4148 calculated in 2010 [13]. We analysed that each type of expenditure on each income group; it gives clear picture to what policy should recommend to government.

In terms of basic education expenditure, it shows (Table IV) that it increases for bottom 60 percent whereas it decreases for the high income class. It denotes that public spending on basic education is progressive. On the contrary, tertiary education spending is regressive as income increases for top 40 percent with a negative result for lowest, low and middle income people. It is seen that rich people in Bangladesh receive more benefit from the government overall expenditure on education.

TABLE IV: PRE AND POST-EXPENDITURE INCOME DISTRIBUTION AND GINI COEFFICIENT

\begin{tabular}{|c|c|c|c|c|c|c|}
\hline Types of Expenditure & Lowest & Low & Middle & High & Highest & Gini Coefficient \\
\hline Pre-Expenditure & $46,973.44$ & $81,911.86$ & $119,981.84$ & $185,048.75$ & $466,152.56$ & \\
\hline Percentage & 5.22 & 9.10 & 13.33 & 20.56 & 51.79 & 0.4184 \\
\hline Post-Exp (Primary & $61,033.94$ & $98,534.23$ & $137,880.89$ & $203,492.52$ & $484,238.86$ & \\
\hline Percentage & 6.20 & 10.00 & 14.00 & 20.66 & 49.15 & 0.3862 \\
\hline Post-Exp (seondary) & $54,462.15$ & $92,152.30$ & $134,959.25$ & $204,525.52$ & $490,619.24$ & \\
\hline Percentage & 5.58 & 9.43 & 13.82 & 20.94 & 50.23 & 0.4032 \\
\hline Post-Exp Tertiary) & $47,757.96$ & $83,282.98$ & $121,941.35$ & $189,163.91$ & $475,754.01$ & \\
\hline Percentage & 5.20 & 9.07 & 13.28 & 20.61 & 51.83 & 0.4193 \\
\hline Post Exp (Total) & $210,227.49$ & $355,881.37$ & $514,763.32$ & $782,230.70$ & $1,916,764.67$ & \\
\hline Percentage & 5.56 & 9.42 & 13.62 & 20.69 & 50.71 & 0.4063 \\
\hline
\end{tabular}

Source: Author's Calculation

\section{F. Gini Coefficient and Income Distribution before and after Public Expenditure}

Before public expenditure on education, the Gini coefficient was 0.4184 which decreased to 0.4063 after the expenditure on primary and secondary education (Table IV). In indicates that inequality decreased. But income inequality increased for tertiary expenditure where Gini coefficient increased to 0.4193 . However the Gini coefficient (0.4063) from overall education describes that income inequality decreased in Bangladesh.

\section{POLICY RECOMMENDATION}

Gini Coefficient shows that overall income inequality decreased in Bangladesh. However, the rich group receive more benefit from the public education expenditure. Urban people get more benefit than that of rural and male students get more than female students. Although government's main objective is to reduce the poverty gap, the poor receive insignificant amount. At this stage, Bangladesh government should rethink their education programmes. Bangladesh government should emphasize on poor and spend more money on primary and secondary education. The projects like stipend for female students in the rural area should continue and extend the coverage. This can also be extended for the male poor students. Non-government organizations like BRAC (a non-government organization) are working in the rural area for providing the education services. Government can coordinate with them. The Bangladesh government can emphasize on higher education for poor by providing special soft loan created only for them and universities should also be adopted the policy so that poor income class people can access the opportunity. Some commercial banks such as Eastern Bank Limited, Dutch Bangla Bank Limited, BRAC Bank have come up to assist the students for higher studies. This can be incorporated as the CSR in every bank. There can be quota system in the enrolment particularly in higher education. There is system of minimizing gap between rural and urban the condition is relaxed for rural student in Bangladesh particularly for grade XI and XII. This increases the percentage of rural people, thus minimizes the gap by region. Government can also suggest universities to give special discount for the students come from poor and comparatively backward areas. Poor students can be encouraged for higher education by providing stipend for continuing the higher studies. This stipend system will encourage them for tertiary education. This system will bring the positive effect for the students come bottom income group [15], [16]. Government can increase the charge and fees for private higher education where normally rich households send their children. By doing so, government can earn more and spend for poor people. For minimizing the inequality, government emphasizes establishing higher education institutions in 
rural areas particularly in those divisions or districts which are far away from the capital city. Government can enact law for prohibiting establishment of new universities in Dhaka city and encourage setting in other districts. This will not only decrease the gap between rural and urban but also to minimize the cyclical effect in the capital city. However, this should be target based and poor districts should be in top most priority.

\section{CONCLUSION}

From the benefit incidence analysis on the public expenditure on education (primary, secondary and tertiary) it seems that education system is pro-poor. The poor people can be benefited more from the primary and secondary education and less benefited from the tertiary education. However, overall expenditure on education is favourable to the poor which proves from the income share of household. Because, income increased from 5.22 to 5.56 for the poorest group after the government expenditure which decreased from 51.79 to 50.71 for the richest group. It indicates the inequality decreases. It is also proved by the Gini coefficient calculated before and after the expenditure on education. The calculated Gini went down from 0.4184 to 0.4063 . Although this is a good sign for the society, the lion's share from the education expenditure at each level is enjoyed by the richest group which is more than half of the total expenditure. It signifies the policy failure and demands Bangladesh government should rethink about the public education system as well as expenditure to provide more benefit to the poor in order to build a sustainable society.

\section{REFERENCES}

[1] P. Buracom, "The Determinants and distributional effects of public education, health and welfare spending in Thailand," Asian Affairs: An American Review, vol. 38, no. 3, pp. 113-142, 2011.

[2] M. R. Karim, "Benefit incidence analysis on Thailand (unpublished)," National Institute of Development Administration, 2013.

[3] S. Sarkar, S. Rana, and R. Zitu, "Challenges of quality higher education in Bangladesh: A study on public universities," Journal of Education and Practice, vol. 4, no. 8, pp. 151-161, 2013.

[4] D. M. Brasington, "Differences in the production of education across regions and urban and rural areas," Regional Studies, vol. 36, no. 2, pp. 137-145, Apr. 2002.

[5] J. Gafar, "The benefit-incidence of public spending: the Caribbean experience," Journal of International Development, vol. 18, no. 4, pp. 449-468, May 2006.

[6] M. Mohsin and M. A. Kamal, "Managing quality higher education in Bangladesh: Lessons from the Singaporean and Malaysian strategies and reforms," International Journal of Business and Management, vol. 7, no. 20, pp. 59-70, Oct. 2012.
[7] J. S. Cuenca, "Benefit incidence analysis of public spending on education in the Philippines: A methodological note," Makati City, pp. 1-20, 2008.

[8] T. M. Selden and M. J. Wasylenko, "Benefit incidence analysis in developing countries Benefit Incidence Analysis in Developing Countries Public Disclosure Authorized," no. 1015, 1992.

[9] E. van de Vliert, "Women and wages worldwide: How the national proportion of working women brings underpayment into the organization," Organization Studies, vol. 25, no. 6, pp. 969-986, Jul. 2004

[10] D. Sagarik, "The analysis of the determinants of education expenditures in Thailand," National Institute of Development Administration, 2012.

[11] E. R. T. Hamid R. Davoodi, and S. S. Asawanuchit, "How useful are benefit incidence analyses of public education and health spending?" Washington, pp. 1-47, 2003.

[12] A. Wagstaf, "Benefit incidence analysis are government health expenditures more pro-rich than we think?" Washington DC, pp. 1-23, 2010.

[13] Coverpage of Bangladesh, HIES Survey Report, Dhaka, 2010

[14] M. Krongkaew, "The distributive impact of government's policies: An assessment of the situation in Thailand," Thamasat University, 1979.

[15] S. Aikman and N. Rao, "Gender equality and girls' education: Investigating frameworks, disjunctures and meanings of quality education," Theory and Research in Education, vol. 10, no. 3, pp. 211-228, Nov. 2012

[16] M. Ahmed, "Multiple providers and access to primary education: The case of Bangladesh," Prospects, vol. 40, no. 3, pp. 393-415, Sep. 2010 .

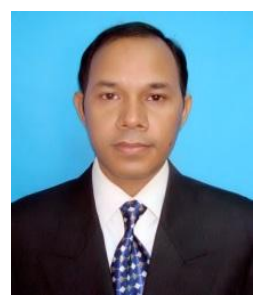

Mohammad Rezaul Karim is a professional trainer in the field of public administration, he actively involved in the development process of human resources especially engaged in Bangladesh Civil Service. Since 2000 he has been working in Bangladesh Public Administration Training Centre (BPATC), an apex public sector training institute of Bangladesh, mandated to impart training to various officials working at different tiers of the government, autonomous and semi-autonomous organizations. Educated in Public Administration from the University of Dhaka, Bangladesh and in Human Resource Management from the University of Leeds, England, Mr. Karim is currently pursuing his $\mathrm{PhD}$ in Development Administration at the Graduate School of Public Administration, National Institute of Development Administration (NIDA), Bangkok, Thailand. As a part of his professional responsibility he conducts training sessions on various issues relating to public administration in different courses conducted by BPATC. He is an experienced researcher in the field of public administration. His recent research issues include recruitment and selection process in Bangladesh, role and reality of female representatives of local government systems in Bangladesh, position of ethnic minorities in labor market, performance management system of government employees in Bangladesh, policy intervention in primary education system in Bangladesh, benefit incidence of public education spending, impact assessment of changing working culture, work-life balance of public and private sector employees, gender pay gap etc. He has three published books and seventeen articles on various issues in different national and international journals in his account. 